\title{
Detection and differentiation of sheeppox virus and goatpox virus from clinical samples using 30 kDa RNA polymerase subunit ( RPO30) gene based PCR
}

\author{
R. Santhamani, R. Yogisharadhya, G. Venkatesan, S. B. Shivachandra, A. B. Pandey and M. A. Ramakrishnan \\ Division of Virology \\ Indian Veterinary Research Institute, Mukteswar, Uttarakhand - 263 138, India \\ Corresponding author: M. A. Ramakrishnan, email: maramakrishnan@gmail.com \\ Received: 20-08-2013, Revised: 18-09-2013, Accepted: 19-09-2013, Published online: 29-10-2013
}

doi: 10.14202/vetworld.2013.923-925 How to cite this article: Santhamani R, Yogisharadhya R, Venkatesan G, Shivachandra SB, Pandey AB and Ramakrishnan MA (2013) Detection and differentiation of sheeppox virus and goatpox virus from clinical samples using 30 kDa RNA polymerase subunit (RPO30) gene based PCR, Veterinary World 6(11): $923-925$.

\begin{abstract}
Aim: To detect and differentiate Capripox virus (sheeppox virus and goatpox virus) infections by using 30 kDa RNA polymerase subunit (RPO30) gene based PCR.

Materials and Methods: Two capripox viruses' viz., sheep pox virus (SPPV) and goatpox virus (GTPV) from clinical samples of different outbreaks were detected and differentiated using capri pox virus (CaPVs) genotyping PCR targeting the CaPV RPO30 gene. By using the above PCR assay, a total of 54 scab samples from pox disease outbreaks occurred in goats $(\mathrm{n}=21)$ and sheep $(\mathrm{n}=33)$ were screened.

Results: Out of 54 clinical samples, 43 [17 out of 21 (80.95\%) goat scabs and 26 out of 33 sheep (78.78\%)] were found positive for capripox virus infection. All positive samples yielded expected amplicon sizes of 172 bp for goatpox virus and $152 \mathrm{bp}$ for sheep pox virus.
\end{abstract}

Conclusion: The current study demonstrated that RPO30 gene based PCR assay could be used for molecular epidemiology of capripox virus infection and differentiation of causative agent viz., sheep pox virus and goatpox virus.

Key words: capripox virus, differentiation PCR, goat pox, RPO30 gene, sheeppox

\section{I ntroduction}

There are many diseases affecting sheep and goats. Among them, sheeppox and goatpox are the two major diseases which are caused by sheeppox virus (SPPV) and goatpox virus (GTPV), respectively. These viruses belong to the genus Capripoxvirus of the family Poxviridae [1]. Capripox is a transboundary disease [1] and was categorized earlier under notifiable diseases by the World Organization for Animal Health [2]. The genus Capripoxvirus (CaPV) also includes lumpy skin disease virus (LSDV), which causes lumpy skin disease/nodular dermatitis in cattle. Sheeppox and goatpox exhibit similar clinical signs characterized by pyrexia and pock lesions in the skin and lungs. Sheeppox and goatpox are endemic in Africa, India, North Equator, Middle East countries including Egypt, Turkey, Iraq, Iran, and Afghanistan, and India [1, 3]. In India, sheeppox and goatpox are have been reported from almost all the states [4-6].

The current criterion used for classifying CaPVs within the genus is based upon the animal species from which the viruses are isolated, viz., SPPV from sheep, GTPV from goats and LSDV from cattle [1].This tends to suggest that CaPVs are strictly host-specific. However, there are several reports indicating the SPPV could infect goats and GTPV could infect sheep [7].

Copyright: The authors. This article is an open access article licensed under the terms of the Creative Commons Attribution License (http://creativecommons.org/licenses/by/2.0) which permits unrestricted use, distribution and reproduction in any medium, provided the work is properly cited.
Therefore, this method of classification is inaccurate [1]. Homologous live attenuated sheeppox and goatpox vaccines $[8,9]$, which are currently in use, offer only partial or no protection under field conditions [8]. This may be due to the use of vaccine strain or field virus with unknown host specificity. Because of these reasons, we are in need of differentiating SPPV and GTPV as well as their host specificity in order to select appropriate vaccine candidate and challenge virus.

As SPPV and GTPV are antigenically closely related, they cannot be differentiated using serological tests [10]. Currently, differentiation of these pathogens using molecular methods such as restriction endonuclease analysis (REA), whole genome sequencing, P32 gene based PCR-RFLP [11], PCR targeting RPO30 gene [12], and GPCR gene based quantitative PCR [13] are available. Among them, PCR targeting RPO30 (RNA polymerase $30 \mathrm{kD}$ subunit gene - ORF036) gene is simple, cheap and quick to differentiate SPPV and GTPV. The present study describes the use of RPO30 gene based PCR for genotype identification of capripox viruses from clinical samples of pox disease outbreaks.

\section{Materials and Methods}

Clinical samples: In the present study, 54 scab samples (33 sheep and 21 goats) which were suspected for pox disease were obtained from repository of Pox Laboratory of Division of Virology, Indian Veterinary Research Institute, Mukteswar, Uttarakhand. These samples were previously collected from various parts of the country 


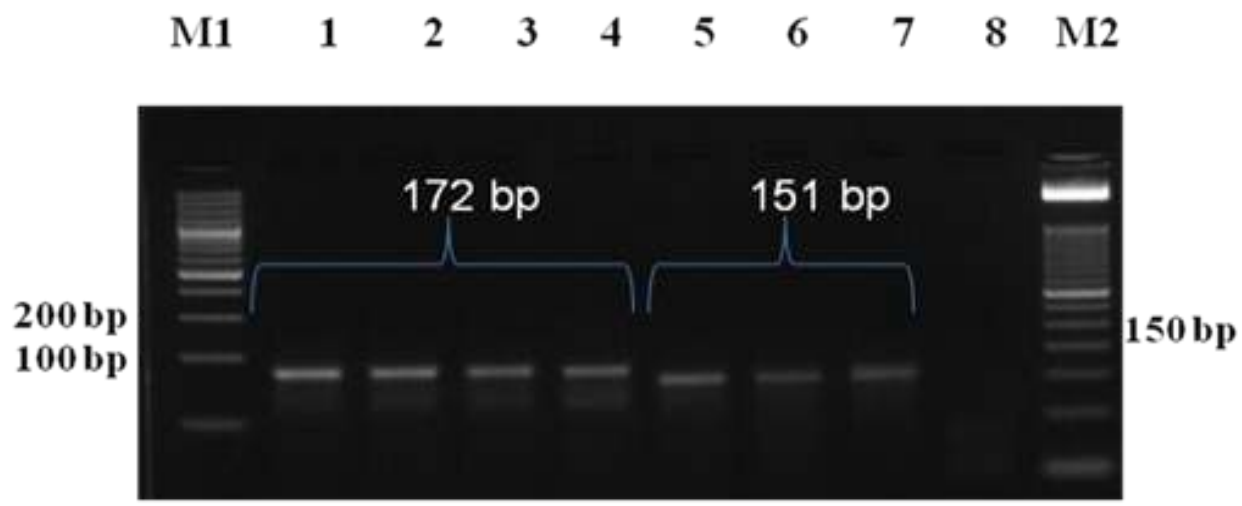

Figure-1. RPO30 gene based PCR assay for differentiation of SPPV and GTPV. Lanes M1-100 bp plus ladder, M2-50 bp ladder, Lanes 1-4 GTPV positive samples, Lanes 5-7 SPPV positive samples, Lane 8 negative control.

between the years 2004 and 2013.

DNA Extraction: Scab samples were triturated and homogenized with $50 \%$ phosphate buffered saline and made into $10 \%$ suspension. DNA from scab samples was extracted using FNES (fast, non-enzymatic and simple) technique [14] with necessary modification. Briefly, $500 \mu \mathrm{L}$ of processed clinical sample was centrifuged at 10,000 $\times \mathrm{g}$ for 3 minutes. The supernatant was discarded and $600 \mu \mathrm{L}$ of DNA extraction buffer [100 mM Tris pH 8.0, $50 \mathrm{mM}$ EDTA pH 8.0, $500 \mathrm{mM}$ $\mathrm{NaCl}, 1.5 \%$ SDS, and $0.3 \%$ B-mercaptoethanol] was added and incubated at $65^{\circ} \mathrm{C}$ for $10 \mathrm{~min}$. About $200 \mu \mathrm{L}$ of $3 \mathrm{M}$ potassium acetate was added and centrifuged at $20,800 \times \mathrm{g}$ for $1 \mathrm{~min}$. The supernatant was transferred to a new tube and equal amount of chilled isopropanol was added and incubated at $4{ }^{\circ} \mathrm{C}$ for $10 \mathrm{~min}$. The mixture was centrifuged at $17,000 \times \mathrm{g}$ for $5 \mathrm{~min}$; the pellet was washed by adding $500 \mu \mathrm{L}$ of $70 \%$ ethanol and was centrifuged at $8000 \times \mathrm{g}$ for $5 \mathrm{~min}$. Finally, the DNA pellet was dried and resuspended in $30 \mu \mathrm{L}$ of nuclease free water.

Polymerase chain reaction: The RPO30 gene based PCR to differentiate GTPV from SPPV [12] was used. The PCR primers used in this study were; SpGp RNA Pol F 5'-tctatgtcttgatatgtggtggtag-3' and SpGpRNA Pol R 5' -agtgattaggtggtgtattattttcc-3' (synthesized by IDT, USA). PCR was carried out in a $25 \mu \mathrm{L}$ reaction volume in a $200 \mu \mathrm{L}$ capacity PCR tube containing 12.5 $\mu \mathrm{L}$ Maxima Hot Start Green PCR Master Mix (Fermentas, USA), $0.5 \mu \mathrm{L}$ of each primer $(10 \mathrm{pmol} / \mu \mathrm{L}), 1 \mu \mathrm{L}$ of extracted DNA and $10.5 \mu \mathrm{L}$ of nuclease free water. DNA extracted from known SPPV and GTPV was kept as positive control whereas nuclease free water was used in negative control. The amplification was performed in a thermocycler (Eppendorf AG, Hamburg, Germany) after initial denaturation at $95{ }^{\circ} \mathrm{C}$ for $4 \mathrm{~min}$, followed by 40 cycles of denaturation at $95^{\circ} \mathrm{C}$ for $30 \mathrm{sec}$, annealing at $55^{\circ} \mathrm{C}$ for $30 \mathrm{sec}$ and extension at $72{ }^{\circ} \mathrm{C}$ for $30 \mathrm{sec}$ and final extension at $72{ }^{\circ} \mathrm{C}$ for $5 \mathrm{~min}$. The PCR products were electrophoresed on $3 \%$ agarose gel for $1 \mathrm{~h}$ at $100 \mathrm{~V}$.

\section{Results}

The modified FNES method yielded a DNA concentration ranging from 13 to $17 \mu \mathrm{g} / \mathrm{mL}$ with OD260/OD280 ratio $>1.8$. Out of 54 clinical samples, 43 [17 out of $21(80.95 \%)$ goat scabs and 26 out of 33 sheep (78.78\%)] were found positive for the capripox virus infection. All positive samples yielded expected product sizes respective to their host origin i.e. $172 \mathrm{bp}$ for goatpox virus and $152 \mathrm{bp}$ for sheeppox virus (Figure-1).

\section{Discussion}

Conventional DNA extraction procedures and commercial spin -column-based kits are time consuming and relatively expensive, [14]. One of the simplest methods of DNA extraction from skin is by boiling the tissue samples $[15,16]$. Sufficient DNA was recovered for PCR amplification, but sometimes, boiling produced thick elutes [15] and non-specific amplification [16]. Recently, a rapid non-enzymatic procedure for extracting camelpox viral DNA from dried scabs was developed to overcome some of the limitations of the currently available DNA extraction techniques [14]. In the present study, in order to enhance the purity of the DNA, the protocol was modified by inclusion of precipitation and washing of DNA, with isopropanol, and 70\% ethanol, respectively.

RPO30 gene of SPPV has a 21-nucleotide deletion in the 5' end compared to GTPV. Primers used in this study bind and amplify the partial RPO30 gene including the 21 nucleotide deletion. As a result SPPV yields the product size (152 bp) which is lesser than the GTPV product size (172 bp). This genotyping PCR was successfully used for identifying SPPV and GTPV in Indian scenario. The same PCR was also used by Lamien et al., 2011 and Yan et al., 2012 [12,17] for $\mathrm{CaPV}$ species identification. Furthermore, similar results were observed with P32 gene based PCR-RFLP [17]. In the present study, all the scab samples tested yielded the product size respective to their host origin.

Earlier, several PCR assays have been developed for the detection of CaPVs $[11,16,18,19,20]$. However, most of them were confined to detect up to genus level. Apart from RPO30 gene based PCR [12] few assays such as P32 gene based PCR-RFLP [11, 21], multiplex 
PCR based on ORF016 [20], and GPCR gene based real time PCR [12] are currently available to differentiate SPPV and GTPV. These assays have demerits like requirement of RE digestion, multiplexing of primers, and sophisticated equipments. The PCR assay used in the current study using RPO30 gene based differentiation PCR, which is simple, robust and cost effective as SPPV and GTPV can be differentiated in a single PCR.

\section{Conclusion}

RPO30 gene based genotyping PCR was found to be robust and reliable to detect and discriminate SPPV and GTPV without the need of labour intensive techniques like gene sequencing and PCR-RFLP. The current study using a limited number of samples indicated that sheeppox and goatpox infections were associated with SPPV and GTPV, respectively. This assay in combination with sequencing can be used for molecular epidemiology of capripox virus infection.

\section{Authors' contributions}

RS, RY, ABP and MAR implemented the study design. RS and MAR carried out the work part. RS, GV, SBS and MAR did the analysis part and wrote the manuscript. All authors read and approved the final manuscript.

\section{Acknowledgements}

The authors thank the Director, Indian Veterinary Research Institute (IVRI), Izatnagar, UP for providing the fund and the facilities to carry out the work.

\section{Competing interests}

The authors declare that they have no competing interests.

\section{References}

1. Babiuk, S., Bowden, T. R., Boyle, D.B., Wallace, D. B., Kitching, R. P. (2008) Capripoxviruses: an emerging world wide threat to sheep, goats a.nd cattle. Transbound. Emerg. Dis. 55: 263-272.

2. International Office of Epizootics. Biological Standards Commission, International Office of Epizootics. International Committee (2008) Manual of diagnostic tests and vaccines for terrestrial animals? mammals, birds, and bees. Office international des épizooties, Paris.

3. Carn, V. M. (1993) Control of capripoxvirus infections. Vaccine 11:1275-1279.

4. Bhanuprakash, V., Indrani, B.K., Hosamani, M. and Singh, R.K. (2006) The current status of sheep pox disease. Comp. Immunol. Microbiol. Infect. Dis. 29:27-60.

5. Mondal, B., Hosamani, M., Dutta, T.K., Senthilkumar, V.S., Rathore, R. and Singh, R.K. (2004) An outbreak of sheep pox on a sheep breeding farm in Jammu, India. Sci. Tech. Rev. 23: 943-949.

6. Verma, S., Verma, L.K., Gupta, V.K., Katoch, V.C., Dogra, V., Pal, B. and Sharma, M. (2011) Emerging Capripoxvirus disease outbreaks in Himachal Pradesh, a northern state of India. Transbound. Emerg. Dis. 58:79-85.
7. Bhanuprakash, V., Venkatesan, G., Balamurugan, V., Hosamani, M., Yogisharadhya, R., Chauhan, R.S., Pande, A., Mondal, B. and Singh, R.K. (2010) Pox outbreaks in sheep and goats at Makhdoom (Uttar Pradesh), India: evidence of sheeppox virus infection in goats. Transbound. Emerg. Dis. 57: 375-382.

8. Hosamani, M., Nandi, S., Mondal, B., Singh, R.K., Rasool, T.J. and Bandyopadhyay, S.K. (2004) A Vero cell-attenuated Goatpox virus provides protection against virulent virus challenge. Acta Virol 48:15-21.

9. Yogisharadhya, R., Bhanuprakash, V., Hosamani, M., Venkatesan, G., Balamurugan, V., Bora, D.P., Bhanot, V., Prabhu, M. and Singh, R.K. (2011) Comparative efficacy of live replicating sheeppox vaccine strains in Ovines. Biologicals 39:417-423.

10. Balinsky, C.A,, Delhon, G., Smoliga, G., Prarat, M., French, R.A., Geary, S.J., Rock, D.L. and Rodriguez, L.L. (2008) Rapid preclinical detection of sheeppox virus by a real-time PCR assay. J. Clin. Microbiol. 46:438-442.

11. Hosamani, M., Mondal, B., Tembhurne, P.A., Bandyopadhyay, S.K., Singh, R.K. and Rasool, T.J. (2004) Differentiation of sheep pox and goat poxviruses by sequence analysis and PCR-RFLP of P32 gene. Virus Genes 29:73-80.

12. Lamien, C.E., Le Goff, C., Silber, R. (2011) Use of the Capripoxvirus homologue of Vaccinia virus $30 \mathrm{kDa}$ RNA polymerase subunit (RPO30) gene as a novel diagnostic and genotyping target: development of a classical PCR method to differentiate Goat poxvirus from Sheep poxvirus. Vet. Microbiol. 149:30-39.

13. Lamien, C.E., Lelenta, M., Goger, W., Silber, R., Tuppurainen, E., Matijevic, M., Luckins, A.G. and Diallo, A. (2011) Real time PCR method for simultaneous detection, quantitation and differentiation of capripoxviruses. J. Virol. Meth. 171: 134140.

14. Yousif, A.A., Al-Naeem, A.A., Al-Ali, M.A. (2010) Rapid non-enzymatic extraction method for isolating PCR-quality camelpox virus DNA from skin. J. Virol. Meth. 169: 138-142.

15. Beard, P.M., Sugar, S., Bazarragchaa, E., Gerelmaa, U., Tserendorj, S., Tuppurainen, E. and Sodnomdarjaa, R. (2010) A description of two outbreaks of capripoxvirus disease in Mongolia. Vet. Microbiol. 142:427-431.

16. Ireland, D.C. and Binepal, Y.S. (1998) Improved detection of capripoxvirus in biopsy samples by PCR. J. Virol. Meth. 74:1-7.

17. Yan, X-M., Chu, Y-F., Wu, G-H., Zhao, Z-X., Li, J., Zhu, H$X$. and Zhang, Q. (2012) An outbreak of sheep pox associated with goat poxvirus in Gansu province of China. Vet. Microbiol. 156:425-428.

18. Heine, H.G., Stevens, M.P., Foord, A.J. and Boyle, D.B. (1999) A capripoxvirus detection PCR and antibody ELISA based on the major antigen P32, the homolog of the vaccinia virus H3L gene. J. Immunol. Meth. 227:187-196.

19. Mangana-Vougiouka, O., Markoulatos, P., Koptopoulos, G., Nomikou, K., Bakandritsos, N. and Papadopoulos, P. (2000) Sheep poxvirus identification from clinical specimens by PCR, cell culture, immunofluorescence and agar gel immunoprecipitation assay. Mol. Cell. Probes 14:305-310.

20. Orlova, E.S., Shcherbakova, A.V., Diev, V.I. and Zakharov, V.M. (2006) Differentiation of capripoxvirus species and strains by polymerase chain reaction. Mol. Biol. (Mosk) 40: $158-164$.

21. Venkatesan, G., Balamurugan, V., Yogisharadhya, R., Kumar, A. and Bhanuprakash, V. (2012) Differentiation of sheeppox and goatpox viruses by polymerase Chain reaction-restriction fragment length polymorphism. Virol. Sin. 27:352-358. 